\title{
PERILAKU BERBELANJA SECARA ONLINE DITINJAU DARI GAYA HIDUP HEDONIS PADA MAHASISWI FAKULTAS PSIKOLOGI ANGKATAN 2013 UNIVERSITAS ISLAM SULTAN AGUNG
}

\author{
Ega Rengganis Putri dan Abdurrohim \\ Fakultas Psikologi, Universitas Islam Sultan Agung \\ Email: abdurrohim@unissula.ac.id
}

\begin{abstract}
Abstrak
Penelitian ini bertujuan untuk mengetahui hubungan antara gaya hidup hedonis dengan perilaku membeli secara online pada mahasiswa Fakultas Psikologi Unissula Semarang. Populasi dalam penelitian adalah mahasiswi angkatan 2013 Fakultas Psikologi Unissula Semarang dengan sampel sebanyak 57 orang. Teknik pengambilan sampel yang digunakan adalah incidental sampling. Skala yang dipakai dalam penelitian ini adalah skala perilaku membeli online dan skala gaya hidup hedonisme. Analisis data dalam penelitian ini menggunakan teknik korelasi product moment. Hasil penelitian menunjukkan bahwa ada hubungan positif yang sangat signifikan antara perilaku membeli secara online dengan gaya hidup hedonisme, artinya makin tinggi gaya hidup hedonisme maka makin tinggi perilaku membeli secara online, dan sebaliknya makin rendah gaya hidup hedonisme maka makin rendah pula perilaku membeli secara online.
\end{abstract}

Kata kunci: Perilaku membeli online, gaya hidup hedonisme.

\section{THE RELATIONSHIP BETWEEN ONLINE BUYING BEHAVIOUR AND HEDONIS LIFESTYLE IN FACULTY OF PSYCHOLOGY STUDENTS AT SULTAN AGUNG ISLAMIC UNIVERSITY}

\begin{abstract}
The aim of this research is to test empirically the relationship between online buying behaviour and hedonis lifestyle. The population in this study were the 2013 students of psychology faculty of Unissula. The sampling technique used incidental sampling. The subjects included in this research are 57 students. This study uses quantitative methods. Data were collected by online buying behaviour scale and hedonis lifestyle scale. The online buying scale consist of 31 items with reliability generated 0,922, while hedonis lifestyle scale consist of 26 items with reliability generated 0,889. Both instruments are reliable. Based on the results of hypothesis testing using correlation techniques Product Moment, $r_{x y}=0.65$ with a significance level of $0.000(p<0.01)$. This result indicate that there is a significant positive relationship between online buying behaviour and hedonis lifestyle. Based on the result of the study, it can be concluded that the lower hedonis lifestyle, the higher online buying behaviour do.
\end{abstract}

Keywords: buying online, hedonis lifestyle. 


\section{Pendahuluan}

Disadari atau tidak budaya kehidupan masyarakat modern telah mengalami perubahan yang besar. Salah satu diantara yang terlihat adalah perkembangan fungsi handphone dan penggunaan internet di masa sekarang. Jika beberapa tahun yang lalu, handphone dan internet merupakan kebutuhan tersier yang hanya digunakan oleh masyarakat yang mempunyai penghasilan yang besar, sebaliknya di masa sekarang handphone dan internet merupakan kebutuhan primer untuk setiap masyarakat yang hidup di era modern seperti sekarang ini. Fenomena lain yang juga menggambarkan perubahan kehidupan masyarakat modern yaitu jika beberapa tahun yang lalu handphone hanya digunakan sebagai alat untuk berkomunikasi, kini handphone mampu menawarkan fasilitas yang lebih baik yaitu sebagai salah satu sarana yang digunakan untuk membantu memenuhi kebutuhan masyarakat masa kini.

Bagaimana handphone dan internet dapat dijadikan sarana memenuhi kebutuhan masyarakat modern. Di masa sekarang ini, waktu luang merupakan hal yang sulit dimiliki oleh masyarakat modern. Masyarakat modern terutama yang tinggal di kota-kota besar sibuk menjalani rutinitas kewajibannya guna memenuhi tuntutan kebutuhan yang harus dipenuhi. Oleh karena itu, masyarakat modern juga dituntut untuk dapat memanfaatkan waktu dengan benar-benar baik. Misalnya melakukan 2 kegiatan dalam 1 waktu, contoh nyatanya yaitu ketika ada sedikit jeda waktu saat bekerja digunakan untuk berbelanja. Dari alasan itulah handphone dan internet hadir sebagai solusi dengan menawarkan fungsi baru yaitu sebagai alat teknologi yang yang bisa dimanfaatkan untuk memberikan fasilitas kehidupan yang lebih baik. Fasilitas yang dimaksudkan tersebut salah satunya adalah berbelanja secara online

Belanja online menurut Sultan \& Nasir (dalam Menkominfo, 2013) adalah proses penjualan dan pembelian barang dan jasa pada World Wide Web. Musriha \& Gilang (2012) mendefinisikan belanja online sebagai perilaku mengunjungi toko online melalui media internet untuk mencari, menawar atau melihat produk dengan niat membeli dan mendapatkan produk tersebut. Berbelanja secara online sangat menguntungkan untuk masyarakat modern yang bisa dibilang hampir tidak mempunyai waktu luang. Dengan hanya bermodal handphone dan internet saja berbelanja dapat dilakukan dengan duduk, ketika sedang menunggu, ketika dalam perjalanan atau sambil makan siang. Bahkan untuk membeli barang yang hanya dijual di luar negeri, kita tidak harus terbang dan mengunjungi negara tersebut.

Pembelian secara online merupakan sebuah terobosan dalam era digitalisasi dunia pemasaran. Berbeda dengan cara belanja konvensional, belanja di internet merupakan cara baru untuk berbelanja. Kemudahan adalah daya tarik utama bagi pembeli produk online.Saat ini, semakin banyak pembeli membeli secara online untuk menghemat waktu mereka, bukan secara fisik mengunjungi toko. Internet telah menjadi sarana penting untuk melaksanakan kegiatan belanja tersebut.

Di Indonesia, data menunjukkan peningkatan minat berbelanja di toko online. Menurut survei Nielsen Global Online, pada tahun 2005 Indonesia menempati urutan ke 14 dari 14 negara di Asia-Pasifik dengan kategori populasi pengguna internet yang pernah 
berbelanja secara online dengan presentase sebesar $42 \%$. Tiga tahun kemudian, yaitu tahun 2008 Indonesia naik satu peringkat dengan menduduki peringkat 13 dengan presentase sebesar 51\%. Sedangkan survai yang dilakukan Office of Fair Traiding tahun 2009 terhadap 1003 konsumen di Inggris menghasilkan 797 konsumen atau sekitar 79\% adalah pelaku belanja online, dimana mereka telah menggunakan internet dalam beberapa waktu dan telah berbelanja online dalam 12 bulan sebelumnya (Kominfo, 2013).

Kemudahan dalam berbelanja secara online-lah yang membuat transaksi dalam bisnis ini terus meningkat. Sultan \& Nasir (dalam Kominfo, 2013) mengungkapkan sebanyak 627 juta orang di seluruh dunia pernah membelanjakan uangnya di toko online. Pada tahun yang sama, harian Kompas pernah menulis fakta yang berdasarkan dari riset yang telah dilakukan oleh lembaga IDC, yaitu nilai perdagangan lewat internet di Indonesia senilai 3,4 million USD atau sekitar 30 triliun rupiah. Data lain menyebutkan, menurut bank dunia sebanyak 56,5\% atau sekitar 134 jiwa di Indonesia yang tergolong ke dalam masyarakat ekonomi kelas menengah membelanjakan uang mereka sekitar 2-20 USD perharinya (Kominfo, 2013).

Boediman berpendapat bahwa transaksi online pada tahun 2010 sampai 2012 meningkat sampai 80\%, selain itu pada tahun 2015 pertumbuhan transaksi online mempunyai potensi untuk meningkat sebesar 19 juta transaksi dengan nilai sebesar 478 juta USD atau sekitar 5 triliun rupiah dimana angka transaksi ini mengalami peningkatan dari sebelumnya yang hanya 12,103 juta transaksi dengan nilai 266 juta USD. Produk yang paling dicari yaitu fashion \& clothing, produk kesehatan dan kecantikan serta gadget (dalam Kabarbisnis.com, 2014).

Penjabaran di atas menunjukkan bahwa minat pengguna internet untuk melakukan belanja secara online sangat tinggi. Adanya berbagai kemudahan yang diperoleh oleh para konsumen saat berbelanja online dapat mempengaruhi dan meningkatkan pembelian konsumen untuk berbelanja secara online. Berbagai kemudahan yang dapat diperoleh oleh konsumen saat berbelanja secara online diantaranya adalah adanya penghematan biaya, barang bisa langsung diantar ke rumah, pembayaran dilakukan secara transfer, dan harga lebih bersaing (Juju \& Maya, 2010).

Meskipun banyaknya resiko atau kemungkinan buruk yang bisa saja terjadi, namun perilaku membeli secara online masih tetap tinggi. Banyak faktor yang mempengaruhi seseorang berbelanja secara online. Faktor-faktor tersebut dipengaruhi oleh banyaknya rangsangan (stimuli) dari luar diri konsumen, baik berupa rangsangan pemasaran maupun rangsangan dari lingkungannya. Rangsangan pemasaran salah satu contohnya dapat terlihat dari sisi kualitas produk, harga, promosi, saluran distribusi, ataupun pelayanan yang diberikan oleh perusahaan sehingga menimbulkan rasa senang atau puas pada diri konsumen. Sementara rangsangan dari lingkungan dapat terlihat dari gaya hidup konsumen untuk menunjukkan citra diri mereka kepada orang lain sehingga konsumen melakukan pembelian secara online. Hal ini didukung oleh pendapat Schiffman dan Kanuk (1999) bahwa konsumen menyukai produk terbedakan yang membuat konsumen merasa mencerminkan kebutuhan khusus, kepribadian dan gaya hidupnya. 
Solomon (2007) mengatakan bahwa gaya hidup mencerminkan pola konsumsi yang menggambarkan pilihan seseorang bagaimana ia menggunakan waktu dan uangnya. Seseorang yang berasal dari subbudaya, kelas sosial, dan pekerjaan yang sama, sangat mungkin memiliki gaya hidup yang berbeda. Dari gaya hidup itulah, dapat menggambarkan keseluruhan tindakan seseorang dengan lingkungannya. Salah satu dari bentuk gaya hidup itu sendiri adalah gaya hidup hedonis.

Gaya hidup hedonis adalah suatu pola hidup yang aktivitasnya untuk mencari kesenangan hidup, seperti lebih banyak menghabiskan waktu diluar rumah, lebih banyak bermain, senang pada keramaian kota, senang membeli barang mahal yang di senanginya, serta selalu ingin menjadi pusat perhatian (Chaney, dalam Kaparang, 2013). Individu dengan gaya hidup hedonis cenderung memiliki nilai kenikmatan, harta benda, dan hiburan. Individu cenderung terlibat dalam kegiatan sehari-hari yang menekankan konsumsi dan kenikmatan(Kunzman 2005).

Gaya hidup hedonis memberikan pengaruh terhadap segala aspek, termasuk dalam hal perilaku belanja online. Gaya hidup hedonis merupakan aspekutama yang mempengaruhi proses pengambilankeputusan seseorang dalam membeli produk (Anggraini,2012). Konsumen tertarik berbelanja karena termotivasi oleh keinginan hedonis atau alasan ekonomi, seperti kesenangan, fantasi dan sosial atau kepuasan emosional. Pengaruh dari gaya hidup hedonis ini, produk yang dibeli cenderung tanpa perencanaan dan akan menghadirkan suatu impulse buying process. Pembelian diawali ketika konsumen melakukan kegiatan pencarian informasi/browsing. Konsumen yang suka berbelanja memiliki kecenderungan lebih besar untuk mencari informasi tentang produk tertentu. Dari informasi yang diperoleh, akan tercipta keinginan untuk memiliki produk tersebut sehingga akan memutuskan melakukan kegiatan pembelian. Konsumen yang memiliki gaya hidup hedonis, ketika melakukan pencarian informasi dapat merasakankesenangan dalam memeriksa unsur-unsur visual pada toko online. Proses pembelian secara online akan semakin besar jika konsumen dapat menemukan produk versi baru dari mode terkini dan citra mereka yang memandu konsumen ke pengalaman gaya hidup hedonis.

Gaya hidup hedonis dapat meningkatkan perilaku pembelian secara online pada konsumen. Individu yang memiliki gaya hidup hedonis tentu akan mencari produk yang mampu memenuhikebutuhan gaya hidupnya melalui berbagai situs belanja online. Seseorang dengan gaya hidup hedonis cenderung tertarik pada display picture barang yang menarik meskipun sebenarnya kurang terlalu membutuhkan barang tersebut. Jika produk yang ditawarkan sesuai dengan keinginan individu tersebut, tentu akan meningkatkan minat pembelian individu. Dengan demikian, gaya hidup hedonis dapat mempengaruhi perilaku seseorang dalam membeli secara online.

Berdasarkan dari beberapa penjabaran di atas maka fokus dari penelitian ini adalah pada perilaku membeli secara online ditinjau dari gaya hidup hedonis, dan penelitian ini akan dilakukan pada mahasiswi angkatan 2013 Fakultas Psikologi Unissula Semarang". 


\section{Perilaku Membeli Online}

Perilaku membeli menggambarkan bagaimana konsumen membuat keputusankeputusan pembelian dan bagaimana menggunakan dan mengatur pembelian barang dan jasa tersebut. Perilaku pembelian akan memberikan petunjuk bagi para pemasar dalam mengembangkan produk baru, keistimewaan produk, harga, saluran pemasaran dan elemen bauran pemasaran lainnya.

Kotler (2008) mendefinisikan perilaku membeli sebagai kebiasaan individu baik secara langsung maupun tidak langsung terlibat dalam mendapatkan serta menggunakan barang dan jasa. Menurut Kotler (2008), perilaku pembelian terdiri dari proses tiga langkah, yaitu pertama pengenalan tentang produk tersebut, kedua mengembangkan keyakinan tentang produk tersebut dan ketiga membuat pilihan pembelian yang cermat.

Engel (Mangkunegara, 2012) mengatakan perilaku membeli adalah proses pengambilan keputusan dan aktivitas individu secara fisik yang dilibatkan dalam proses mengevaluasi, memperoleh, menggunakan atau dapat mempergunakan barang dan jasa. Menurut Sunyoto (2013), perilaku membeli adalah tindakan-tindakan yang dilakukan individu, kelompok atau organisasi yang berhubungan dengan proses pengambilan keputusan dalam mendapatkan, menggunakan barang atau jasa ekonomis yang dapat dipengaruhi oleh lingkungan.

Swastha dan Handoko (2005) mengatakan perilaku membeli adalah kegiatankegiatan individu yang secara langsung terlibat dalam proses mendapatkan dan mempergunakan barang-barang dan jasa, termasuk di dalamnya proses pengambilan keputusan pada persiapan dan penentuan-penentuan kegiatan-kegiatan tersebut. Menurut Kotler dan Amstrong (2009), perilaku membeli adalah perilaku pembelian akhir dari konsumen, baik individual maupun rumah tangga yang membeli barang-barang dan jasa untuk konsumsi pribadi, secara umum konsumen mengikuti suatu proses atau tahapan dalam pengambilan keputusan.

Schiffman dan Kanuk (2010) menjelaskan perilaku membeli adalah perilaku yang diperlihatkan konsumen dalam mencari, membeli, menggunakan, mengevaluasi dan menghabiskan produk dan jasa yang mereka harapkan akan memuaskan kebutuhan mereka. Sumarwan (2010) menyatakan perilaku membeli adalah semua kegiatan, tindakan serta proses psikologis yang mendorong tidakan tersebut pada saat sebelum membeli, ketika membeli, menggunakan, menghabiskan produk dan jasa setelah melakukan hal-hal diatas atau kegiatan mengevaluasi.

Kotler (2008) menjelaskan bahwa aspek-aspek perilaku membeli, yaitu:

a. Pengenalan kebutuhan;Proses pembelian dimulai dengan pengenalan kebutuhan. Pembeli menyadari suatu masalah atau kebutuhan. Kebutuhan dapat dipicu rangsangan internal, seperti rasa lapar, rasa haus, yang timbul pada tingkat yang cukup tinggi sehingga menjadi dorongan. Kebutuhan juga bisa dipicu oleh rangsangan eksternal, seperti iklan atau diskusi yang bisa membuat seseorang untuk membeli suatu produk.

b. Pencarian informasi; Merupakan tahap proses keputusan pembeli dimana konsumen ingin mencari informasi lebih banyak, tahap dimana konsumen memperbesar 
perhatian atau melakukan pencarian informasi secara aktif. Konsumen yang tertarik akan mencari lebih banyak informasi.

c. Evaluasi alternatif; Evaluasi alternatif merupakan tahap dimana konsumen menggunakan informasi untuk mengevaluasi merek alternatif dalam sekelompok pilihan. Bagaimana cara konsumen mengevaluasi alternatif bergantung pada konsumen pribadi dan situasi pembelian tertentu.

d. Keputusan pembelian; Keputusan pembelian konsumen adalah keputusan pembeli tentang merek mana yang dibeli. Konsumen membentuk niat pembelian berdasarkan faktor-faktor seperti pendapatan, harga, dan manfaat produk yang diharapkan.

e. Perilaku setelah membeli; Merupakan tahap dimana konsumen mengambil tindakan selanjutnya setelah pembelian berdasarkan kepuasan atau ketidakpuasan mereka. Kepuasan atau ketidakpuasan konsumen terletak pada hubungan antara ekspektasi konsumen dan kinerja produk. Jika produk tidak memenuhi ekspektasi konsumen, konsumen kecewa; jika produk memenuhi ekspektasi konsumen, konsumen puas; jika produk melebihi ekspektasi konsumen, konsumen sangat puas.

\section{Gaya Hidup Hedonis}

Hedonisme adalah pandangan hidup yang menganggap bahwa kesenangan dan kenikmatan materi adalah tujuan utama hidup. Bagi para penganut paham ini, bersenangsenang, pesta-pora, dan plesiran merupakan tujuan utama hidup, entah itu menyenangkan bagi orang lain atau tidak. Kaum hedonis beranggapan hidup ini hanya sekali, sehingga merasa ingin menikmati hidup senikmat-nikmatnya.Menurut para penganut paham ini, hidup dijalani dengan sebebas-bebasnya demi memenuhi hawa nafsu yang tanpa batas (Praja \& Damayantie, 2013).

Pendapat Kotler (2005),gaya hidup hedonis adalah pola hidup seseorang di dunia yang diekspresikan dalam aktivitas, minat dan opini. Hal senada juga diungkapkan oleh Widjaja (2009) yang menyatakan bahwa gaya hidup hedonis adalah pola hidup yang menggambarkan kegiatan, ketertarikan dan opini individu yang berinteraksi dengan lingkungan sekitarnya dan cara pengukurannya dengan psychographics.

Salam (2002) mengatakan bahwa hedonisme berasal dari bahasa Grik yaitu hedone, yang berarti kesenangan, pleasure, orang-orang yang menganut aliran ini, dengan sendirinya menganggap atau menjadikan kesenangan sebagai tujuan hidupnya.

Gaya hidup merupakan wujud dari suatu reaksi dari aktivitas, minat dan opini. Olehkarena itu dapat dikatakan jika seseorangmenghabiskan banyak waktu dan uang untukhal-hal yang tidak berguna, tidak sesuaidengan kebutuhan terlebih lagi hanya untukkesenangan semata, maka gaya hidup sepertiini dapat dikategorikan sebagai gaya hidup hedonis (Sallina, 2011).

Levan`s \& Linda (2003) berpendapat bahwa gaya hidup hedonis adalah pola perilaku yang dapat diketahui dari aktifitas, minat maupun pendapat yang selalu menekankan pada kesenangan hidup. Lebih lanjut Susianto (1993) menjelaskan bahwa gaya hidup hedonis adalah pola hidup yang mengarahkan aktivitasnya untuk mencari kesenangan hidup dan aktivitas tersebut berupa mengabiskan waktu di luar rumah, lebih banyak bermain, senang 
pada keramaian kota, senang membeli barang yang kurang diperlukan dan selalu ingin menjadi pusat perhatian.

Gaya hidup hedonis yang berorientasi pada kesenangan, umumnya banyak ditemukan dikalangan remaja. Menurut Monks (Masmuadi \&Rachmawati, 2009), remaja memang menginginkan agar penampilan, gaya tingkah laku, cara bersikap, dan lain-lainnya akan menarik perhatian orang lain, terutama kelompok teman sebaya. Remaja yang ingin diakui eksistensinya oleh lingkungan sosialnya berusaha untuk mengikuti perkembangan yang terjadi seperti cara berpenampilan).

Prinsip hedonisme ini menganggap bahwa hal yang baik merupakan sesuatu yang mendatangkan kesenangan, sedangkan sesuatu yang mendatangkan kesusahan, penderitaan, atau tidak menyenangkan merupakan hal yang tidak baik.Seseorang yang menganut prinsip hedonisme menjadikan kesenangan sebagai tujuannya hidupnya. Kecenderungan gaya hidup hedonisyang biasanya dilakukan oleh remaja yang berstatus mahasiswa, seperti lebih banyak mengisi waktu luang di mall atau shopping centre, memiliki sejumlah barang dengan merek-merek tertentu dan prestisius serta cenderung untuk mengikuti mode yang sedang tren (Martha dan Setyawan, 2010). Dengan adanya kecenderungan gaya hidup hedonis tersebut memicu remaja untuk mempersepsikan bahwa individu lainnya sebagai sosok yang human having.

Well dan Tigert (dalam Riaton, 2012) berpendapat bahwa aspek-aspek gaya hidup hedonis adalah:

a. Minat; Minat diartikan sebagai apa yang menarik dari suatu lingkungan individu tersebut memperhatikannya. Minat dapat muncul terhadap suatu objek, peristiwa, atau topik yang menekan pada unsur kesenangan hidup. Antara lain adalah fashion, makanan, benda-benda mewah, tempat berkumpul, dan selalu ingin menjadi pusat perhatian.

b. Aktivitas; Aktivitas yang dimaksud adalah cara individu menggunakan waktunya yang berwujud tindakan nyata yang dapat dilihat. Misalnya lebih banyak menghabiskan waktu di luar rumah, lebih banyak membeli barang-barang yang kurang diperlukan, pergi ke pusat pembelanjaan dan kafe.

c. Opini; Opini adalah pendapat seseorang yang diberikan dalam merespon situasi ketika muncul pernyataan-pernyataan atau tentang isu-isu sosial dan produk-produk yang berkaitan dengan hidup.

\section{Metode Penelitian}

\section{Definisi Operasional}

a. Perilaku membeli online adalah proses pencarian, penawaran dan pembelian barang atau jasa dari penjual melalui media internet menggunakan sebuah webbrowser tanpa harus bertatap muka secara langsung.

b. Gaya hidup hedonis adalahsuatu pola hidupyang mengarahkan individu untuk mencapai kesenangan dan kepuasan pribadi, sehingga bentuk perilaku yang dimunculkan dalam perilaku hedonis biasanya lebih banyak menghabiskan waktu 
untuk bersenang-senang, membeli barang yang tidak diperlukan dan selalu ingin menjadi perhatian di lingkungan sekitarnya.

\section{Subjek Penelitian}

mahasiswi angkatan 2013 Fakultas Psikologi Unissula Semarang. Karakteristik subjek penelitian ini adalah:

1. Mahasiswa angkatan 2013 Fakultas Psikologi yang masih aktif.

2. Pernah melakukan transaksi/pembelian produk secara online.

\section{Metode Pengumpulan Data}

Metode pengumpulan data yang digunakan dalam penelitian ini adalah metode skala. Metode skala dalam penelitian ini menggunakan distribusi respon sebagai dasar penentuan nilai skalanya, yaitu: SS (sangat sesuai), S (sesuai), TS (tidak sesuai), dan STS (sangat tidak sesuai). Skor yang diberikan untuk masing-masing butir pada skala berkisar antara 1 sampai 4.Ada dua jenis skala yang digunakan dalam penelitian ini, yaitu skala perilaku membeli online, dan skala gaya hidup hedonis.

\section{Metode Analisis Data}

Metode analisis yang digunakan adalah teknik korelasi product moment dengan menggunakan alat bantu komputerisasi dengan program SPSS (Statistical Product and Service Solutions) versi 22.0 .

\section{Hasil Penelitian}

Uji hipotesis dalam penelitian ini menggunakan teknik korelasi Product Moment.Berdasarkan uji hipotesis diperoleh nilai korelasi $r_{x y}=-0,65$ dengan $p=0,000(p<$ $0,01)$ dan koefisien determinasi $R^{2}=0,422$. Hasil tersebut menunjukkan bahwa ada hubungan positif yang sangat signifikan antara perilaku membeli secara online dengan gaya hidup hedonism pada Mahasiswi Angkatan 2013 Universitas Islam Sultan Agung Kota Semarang. Berdasarkan hasil tersebut, hipotesis yang diajukan dalam penelitian ini diterima.

Adapun sumbangan efektif yang diberikan variabel perilaku membeli secara online dengan gaya hidup hedonisme sebesar $42,2 \%$, sedangkan $57,8 \%$ yang lainnya dipengaruhi oleh variabel lain di luar variabel yang digunakan dalam penelitian ini, di antaranya adalah faktor sosial dan budaya, usia, pekerjaan, kepribadian, konsep diri, segi psikologis seperti motivasi, persepsi, keyakinan, dan sikap.

\section{Pembahasan}

Berdasarkan hasil penelitian menunjukkan bahwa ada hubungan positif yang sangat signifikan antara gaya hidup hedonis dengan perilaku membeli secara onlinepada mahasiswi. Hal ini dapat dilihat dari nilai korelasi $r_{x y}=0,65$ dengan $p<0,01$. Adapun sumbangan efektif variabel gaya hidup hedonis terhadap perilaku membeli secara online 
sebesar $42,2 \%$, sedangkan $57,8 \%$ yang lainnya dipengaruhi oleh variabel lain di luar variabel yang digunakan dalam penelitian ini.

Hasil penelitian di atas menunjukkan bahwa hipotesis dalam penelitian ini terbukti. Hasil penelitian ini sesuai dengan pendapat yang dikemukakan oleh Anggraini (2012) bahwa gaya hidup hedonis memberikan pengaruh terhadap segala aspek, termasuk dalam hal perilaku belanja online. Gaya hidup hedonis merupakan aspek utama yang mempengaruhi proses pengambilan keputusan seseorang dalam membeli produk. Konsumen tertarik berbelanja karena termotivasi oleh keinginan hedonis atau alasan ekonomi, seperti kesenangan, fantasi dan sosial atau kepuasan emosional. Pembelian diawali ketika konsumen melakukan kegiatan pencarian informasi/browsing. Konsumen yang suka berbelanja memiliki kecenderungan lebih besar untuk mencari informasi tentang produk tertentu. Konsumen yang memiliki gaya hidup hedonis, ketika melakukan pencarian informasi dapat merasakan kesenangan dalam memeriksa unsur-unsur visual pada toko online. Proses pembelian secara online akan semakin besar jika konsumen dapat menemukan produk versi baru dari mode terkini dan citra merek yang memandu konsumen ke pengalaman gaya hidup hedonis.

Belanja online merupakan suatu bentuk transaksi elektronik yang memungkinkan konsumen untuk langsung membeli barang atau jasa dari penjual melalui internet menggunakan browser web. Orang cukup duduk didepan komputer, laptop, atau smart gadget dan memesan barang kesukaannya. Dibandingkan dengan toko offline, toko online lebih banyak memiliki keuntungan. Belanja online menyediakan beberapa alternatif yang menarik yaitu pengeceran memungkinkan kita menjelajah, memilih, memesan dan membayar cukup dengan sekedar menekankan jari telunjuk ke tombol mouse computer" (Kotler \& Armstrong, 2001).

Ollie (2008) berpendapat bahwa manfaat dari belanja melalui online adalah memberikan kemudahan karena pelanggan dapat memesan produk dalam waktu 24 jam sehari dimanapun berada sehingga tidak perlu ribet; adanya kejelasan informasi karena pelanggan dapat memperoleh beragam informasi komparatif tentang perusahaan, produk dan pesaing tanpa meninggalkan pekerjaan yang dilakukan oleh pelanggan; dan tingkat keterpaksaan yang lebih sedikit karena pelanggan tidak perlu menghadapi atau atau melayani bujukan dari faktor-faktor emosional. Bagi konsumen belanja online akan membuat waktu belanja lebih singkat. Konsumen tidak perlu datang secara langsung ke berbagai pertokoan untuk mendapatkan barang yang diinginkan, dan pada toko online biasanya harga yang ditawarkan lebih murah dibanding dengan yang dijual di toko biasanya karena biaya distribusi dari pihak produsen ke konsumen akan lebih pendek.

Kecenderungan berbelanja online biasanya lebih banyak dilakukan oleh remaja putri yang berstatus sebagai mahasiswi.Perilaku belanja online sudah merajalela dikalangan mahasiswi, karena barang yang ditawarkan dan karena pengaruh teman di sekitarnya. Karena belanja online merupakan cara belanja yang memudahkan untuk mahasiswi dan menarik mahasiswi membeli barang dengan hanya tampilan yang ditawarkan saja. Selain itu, melalui perilaku belanja online ini mahasiswi ingin menunjukkan kepada masyarakat dan lingkungannya bahwa mereka sama dan bisa berada diantara kelompoknya dengan 
gaya hidup yang sama. Tren belanja online sekarang sudah menjadi gaya hidup dan kebiasaan bagi mahasiswi untuk memenuhi kebutuhannya. Bagi mahasiswi penampilan merupakan cara mereka manunjukkan jati diri, cara berkomunikasi dan juga menunjukkan mereka pantas berada dalam suatu kelompok tertentu.

Kecenderungan perilaku belanja dipengaruhi oleh beberapa faktor yang pada intinya dapat dibedakan menjadi dua faktor, yaitu faktor eksternal dan faktor internal (Engel, Blackwell \& Miniard, 1995; Kotler, 2006). Salah satu faktor internal yang mempengaruhi perilaku konsumtif adalah gaya hidup hedonis. Hal tersebut sejalan dengan pendapat Triyaningsih bahwa kebanyakan orang yang melakukan perilaku belanja dikarenakan keinginan mengikuti trend gaya hidup. (Triyaningsih, 2011).

Hedonisme adalah pandangan hidup yang menganggap bahwa kesenangan dan kenikmatan materi adalah tujuan utama hidup. Hedonisme sebagai suatu budaya yang meletakkan dimensi kepuasan materi sebagai suatu tujuan utama memicu dan memacu pemanfaatan alam dan atau melakukan aktivitas hidup yang jauh dari dimensi spritual (moralitas) (Praja \& Damayantie, 2013).

Gaya hidup hedonis menjadi topik dalam kaitannya dalam pembelian online.Gaya hidup menurut Assel (Arieffy, 2008) adalah pola kehidupan sehari-hari yang diwujudkan kedalam bentuk aktivitas, minat, dan opini. Pada era modernisasi gaya hidup menjadi sesuatu yang penting yang harus dilakukan dan diikuti oleh semua orang. Gaya hidup menjadikan seseorang lebih memperhatikan lingkungan sekitar jika hal tersebut berkaitan dengan dunia fashion, tren masa kini, dan budaya-budaya modern apa yang sedang banyak disukai.

Mahasiswi dengan gaya hidup hedonis cenderung memiliki nilai kenikmatan, harta benda, dan hiburan. Konsisten dengan nilai-nilai, individu cenderung terlibat dalam kegiatan sehari-hari yang menekankan konsumsi dan kenikmatan.Gaya hidup hedonis mencakup nilai-nilai dan kegiatan sehari-hari yang berkaitan dengan persetujuan sosial dan keintiman (Kunzman 2005).

Gaya hidup hedonis dapat meningkatkan perilaku pembelian secara online pada konsumen. Individu yang memiliki gaya hidup hedonis tentu akan mencari produk yang mampu memenuhi kebutuhan gaya hidupnya melalui berbagai situs belanja online. Seseorang dengan gaya hidup hedonis cenderung tertarik pada display picture barang yang menarik meskipun sebenarnya kurang terlalu membutuhkan barang tersebut. Jika produk yang ditawarkan sesuai dengan keinginan individu tersebut, tentu akan meningkatkan minat pembelian individu. Dengan demikian, gaya hidup hedonis dapat mempengaruhi perilaku seseorang dalam membeli secara online.

\section{Kesimpulan}

Berdasar hasil penelitian pada bab sebelumnya, diperoleh koefisien korelasi $r_{x y}$ sebesar $-0,65$ dengan $p<0,01$, sehingga dapat disimpulkan bahwa ada hubungan positif yang sangat signifikan antara perilaku membeli secara online dengan gaya hidup hedonisme, artinya makin tinggi gaya hidup hedonisme maka makin tinggi perilaku membeli secara online, dan sebaliknya makin rendah gaya hidup hedonisme maka makin 
rendah pula perilaku membeli secara online. Sumbangan efektif yang diberikan variabel gaya hidup hedonisme terhadap variabel perilaku membeli secara online adalah sebesar $42,2 \%$, sedangkan sisanya sebesar $57,8 \%$ dipengaruhi oleh variabel lain diluar variabel yang digunakan dalam penelitian ini. Jadi hipotesis yang diajukan dalam penelitian ini diterima.

\section{Saran}

Mahasiswi diharapkan dapat memahami dengan baik makna 3 kebutuhan, yaitu kebutuhan primer, sekunder, dan tersier. Serta kemudian dapat menempatkan kebutuhan primer sebagai prioritas, sehingga dapat memilah dan memilih mana yang harus dibeli dan mana yang tidak harus dibeli. Sehingga dapat menghindari pembelian barang-barang yang kurang bermanfaat

Bagi peneliti mendatang diharapkan agar dapat meneliti dengan memperhatikan variabel-variabel lain yang berpengaruh terhadap perilaku membeli secara online. Secara teoritis, faktor-faktor yang mempengaruhi perilaku membeli adalah faktor sosial dan budaya, faktor individu, dan faktor psikologi. Faktor individu seperti usia, pendidikan, jenis kelamin, pengetahuan, kepribadian dan konsep diri sedangkan faktor lingkungan adalah faktor yang berasal dari luar individu seperti nilai budaya, lingkungan sekitar dan dukungan sosial dan sebagainya. Selain itu, bagi peneliti mendatang disarankan untuk memperbaiki kelemahan penelitian ini, yaitu melakukan uji coba penelitian sehingga diperoleh skala yang berkualitas, memperbaiki teknik pengambilan sampel dan memperbaiki skala sehingga mudah dipahami oleh responden.

\section{Daftar Pustaka}

Ajzen, I. 2005.The Theory of Planned Behavior. Organizational Behavior andHuman Decision Processes.Vol. 50, h.179-211.

Anggraini, E. 2012.Pengalaman Komunikasi Konsumen Wanita dengan Gaya Hidup Brand Minded.Naskah Publikasi. Semarang: Universitas Diponegoro.

Arieffy, S. 2008. Dugem: Gaya Hidup Hedonis di Kalangan Anak Muda. Jurnal Ilmiah Psikologi. Vol.10.

Babin, JB. 2004. Work and or Fun: Measuring Hedonic and Utilitarian Shopping Value.Journal of Consumer Research. Vol 20, pp. 91-100.

Barten, K. 2002. Etika. Jakarta: Gramedia.

Brigham, JC. 2004. Social Psychology.Canada: Litle, Brown \& Company.

Dayakisni, T.\&Yuniardi, S. 2004.Psikologi Lintas Budaya. Malang: UMM Press.

Ellitan, L. 2008.Supply Chain Management. Cetakan Pertama. Bandung: Penerbit Alfabeta.

Engel, J. F., Blackwell, R. D., \& Miniard, P.W., 1995. Consumer Behavior.Eight edition. Orlando: The Dryden Press.

Karlina, A. 2016. Hubungan Gaya Hidup Hedonis dan Jenis Pekerjaan terhadap Penerimaan Diri Menghadapi Pensiun padaPegawai Negeri Sipil di Kota Samarinda. eJournal Psikologi. Vol. 4 (1), h.144-155. 
Kotler, P. \& Amstrong, G. 2009. Prinsip-Prinsip Pemasaran, Jilid II Edisi Kedelapan. Jakarta: PT Indeks.

Kotler, P. \& Amstrong, G. 2009. Prinsip-Prinsip Pemasaran. Jilid I. Edisi Kedelapan. Jakarta: PT Indeks.

Kotler, P. 2008. Prinsip-prinsip Pemasaran. Jilid 1. Edisi 12. Jakarta: Erlangga

Levant's \& Linda. 2003. What Is Metroseksual Eaurosel. Journal of International. New Delhi.

Mangkunegara, AAAP. 2012. Perilaku Konsumen. Edisi Revisi. Cetakan Kelima. Bandung: PT. Refika Aditama.

Martha, Dkk. (2008). Correlation Among Self EsteemWith a Tendency Hedonist Lifestyle of Student Diponegoro University. Journal of Applied Psychology. Semarang: FAPSI UNDIP..

Myers, GE.\& Myers, MT. 2005. The Dynamics Human Comunications.Singapore: McGrawHill.

Ollie. 2008. Membuat Toko Online dengan Multiply. Jakarta: Media Kita.

Ozen, H. \& Engizek, N. (2014). Shopping Online Without Thinking: Being Emotional or Rational? Asia Pacific Journal of Marketing and Logistics. Vol. 26(1), h.78-93.

Prabowo dan Suwarsi. 2009. Pengaruh Shopping Orientations dan Gender Differences pada Online Information Search dan Online Purchase. Fokus Manajerial. Vol. 7, No. 2.

Praja, DD. \& Damayantie, A. 2013. Potret Gaya Hidup Hedonisme Di Kalangan Mahasiswa (Studi pada Mahasiswa Sosiologi FISIP Universitas Lampung). Jurnal Sociologie. Vol. 1, No. 3, h.184-193.

Rumlus, KW.\& Junaedi, S. 2015. Pengaruh Risiko-Risiko Pembelian padaSikap dan Perilaku Pembelian secaraOnline.Jurnal. Yogyakarta: Universitas Atma Jaya.

Sari, CA. 2015.Perilaku Berbelanja Online di Kalangan Mahasiswi Antropologi Universitas Airlangga. AntroUnairdotNet. Vol.IV/No.2/Juli 2015, h.205-216.

Schiffman, L. \& Kanuk, LL. 2010. Perilaku Konsumen. Jakarta: PT Indeks.

Sumarwan, U. 2010. Perilaku Konsumen, Teori danPenerapannya dalam Pemasaran. Jakarta: Gramedia.

Susianto. 1993.Studi Gaya Hidup Sebagai UpayaMengenali Kebutuhan Anak Muda.JurnalPsikologi dan Masyarakat.Jakarta:Gramedia Widiasarana Indonesia

Swastha, B. \& Handoko, H. 2005. Manajemen Pemasaran: Analisis Perilaku Konsumen. Yogyakarta: BPFE.

Thohiroh, AQ.\& Yuwono, S. 2015. Perilaku Konsumtif Melalui Online ShoppingFashionpada Mahasiswi Fakultas Psikologi UniversitasMuhammadyah Surakarta.Naskah Publikasi. Surakarta: Universitas Muhammadiyah Surakarta.

Triyaningsih, SL. 2011. Dampak Online Marketing Melalui Facebook Terhadap Perilaku Konsumtif Masyarakat. Dalam http://ejournal.unisridigilib.ac.id/index.php/Ekonomi/article/download/66/39

Widjaja, BT. 2009. Life Style Marketing. Jakarta: Gramedia Pustaka Utama. 